\title{
Comparative susceptibility of rainbow trout Oncorhynchus mykiss and brown trout Salmo trutta to Myxobolus cerebralis, the cause of salmonid whirling disease
}

\author{
Ronald P. Hedrick ${ }^{1, *}$, Terry S. McDowell ${ }^{1}$, Melanie Gay ${ }^{1}$, Gary D. Marty ${ }^{2}$, \\ Marios P. Georgiadis ${ }^{1}$, Elizabeth MacConnell ${ }^{3}$ \\ 'Department of Medicine and Epidemiology, School of Veterinary Medicine, University of California, One Shields Avenue, \\ Davis, California 95616, USA \\ ${ }^{2}$ Department of Anatomy, Physiology and Cell Biology, School of Veterinary Medicine, University of California, \\ One Shields Avenue, Davis, California 95616, USA \\ ${ }^{3}$ Montana Fish, Wildlife \& Parks, 1400 S. 19th Avenue, Bozeman, Montana 59715, USA
}

\begin{abstract}
The susceptibility of rainbow trout Oncorhynchus mykiss and brown trout Salmo trutta to Myxobolus cerebralis, the cause of salmonid whirling disease, was assessed following dosed exposures to the infectious stages (triactinomyxons). Parallel groups of age-matched brown trout and rainbow trout were exposed to $10,100,1000$ or 10000 triactinomyxons per fish for $2 \mathrm{~h}$ and then placed in aquaria receiving single pass $15^{\circ} \mathrm{C}$ well water. Severity of infection was evaluated by presence of clinical signs (whirling and/or black tail), prevalence of infection, severity of microscopic lesions, and spore counts 5 mo after exposure. Clinical signs of whirling disease, including a darkened caudal region (black tail) and radical tail chasing swimming (whirling), occurred first among rainbow trout at the highest dose at 6 to $7 \mathrm{wk}$ post exposure. Black tail and whirling occurred among rainbow trout receiving 1000 and 100 triactinomyxons per fish at 8 to $9 \mathrm{wk}$ post exposure. Only 1 of 20 fish had a black tail among rainbow trout receiving 10 triactinomyxons per fish, although $30 \%$ of the fish were infected at 5 mo post exposure. Black tails were observed in brown trout at 1000 and 10000 triactinomyxons per fish beginning at 11 and $7 \mathrm{wk}$ post exposure, respectively. There was no evidence of the tail chasing swimming (whirling) in any group of brown trout. The prevalence of infection, spore numbers, and severity of microscopic lesions due to $M$. cerebralis among brown trout were less at each exposure dose when compared to rainbow trout. Infections were found among rainbow trout at all doses of exposure but only among brown trout exposed to doses of 100 triactinomyxons per fish or greater. Risk of infection analyses showed that rainbow trout were more apt to be infected at each exposure dose than brown trout. Spore counts reached $1.7 \times 10^{6}$ per head among rainbow trout at the highest dose of exposure compared to $1.7 \times 10^{4}$ at the same exposure dose among brown trout. Spore numbers increased with dose of exposure in rainbow trout but not in brown trout. As microscopic lesion scores increased from mild to moderate, spore numbers increased in rainbow trout but not brown trout. The mechanisms by which brown trout resist infections with $M$. cerebralis were not determined. Cellular immune functions, including those of eosinophilic granular leukocytes that were more prominent in brown trout than rainbow trout, may be involved.
\end{abstract}

KEY WORDS: Myxozoan - Myxobolus cerebralis - Whirling disease - Brown trout

\section{INTRODUCTION}

Whirling disease of rainbow trout is caused by Myxobolus cerebralis, a myxozoan parasite possessing

•E-mail: rphedrick@ucdavis.edu a life cycle well adapted to the natural environments where salmonid fish are found (Hedrick et al. 1998). Whirling disease was first described in Europe in 1898 among farmed rainbow trout (Hofer 1903). The parasite was presumably spread throughout Europe with fish movements and then imported to the USA in the 
1950s with shipments of frozen trout (Hoffman 1970). Whirling disease was initially a severe problem for hatchery-reared salmonids but by altering management practices that minimized infections of young fish, the disease could be partially controlled (Schäperclaus 1986). Unfortunately, while gross signs of whirling disease (black tail and radical tail chasing swimming) were controlled, the fish remained infected and served as carriers spreading the parasite into both captive and wild trout populations (Yoder 1972). Beginning in $1990, M$. cerebralis was shown to be associated with severe negative impacts on wild rainbow trout in North America (Nehring \& Walker 1996, Vincent 1996). The devastating losses of wild rainbow trout in the intermountain region of the USA have created a renewed interest in the potential effects of the parasite on native and introduced fish including brown trout.

Historically, the most susceptible salmonid host to Myxobolus cerebralis is rainbow trout (Hofer 1903, Schäperclaus 1931, Hoffman \& Putz 1969, Halliday 1976, O'Grodnick 1979, Hoffman 1990, Markiw 1992a). A range in susceptibility exists among other salmonid fish from quite resistant to highly susceptible (El-Matbouli et al. 1992). The first reports of the disease in Europe documented the serious nature of the disease among rainbow trout, a newly introduced species from North America, in contrast to brown trout as native to Europe that were viewed as resistant (Hofer 1903). Similar patterns of susceptibility and resistance were noted in more controlled exposures of several species of salmonids to waters in a stream or hatchery known to contain infectious stages (Hoffman \& Putz 1969, Halliday 1976, O'Grodnick 1979). These differences in susceptibility/resistance between rainbow and brown trout were cited as evidence that the parasite evolved in Eurasia with the latter species (Hoffman 1970, 1990). While this hypothesis applies to brown trout resistance, it fails to explain the high susceptibility to whirling disease of the European Danube salmon Hucho hucho (El-Matbouli et al. 1992) or the resistance of coho salmon Oncorhynchus kisutch (O'Grodnick 1979) native to western North America. More controlled comparisons of the relative susceptibility of different salmonids to $M$. cerebralis were made possible by the pioneering studies on the parasite's life cycle by Wolf \& Markiw (1984). They demonstrated that the infectious stages (triactinomyxons) of the parasite for the salmonid fish could be propagated by infecting laboratory populations of the aquatic oligochaete Tubifex tubifex with spores from infected trout.

We compared the relative susceptibility of age matched brown and rainbow trout to selected doses of triactinomyxons and then held these fish under controlled laboratory conditions. These comparisons allowed us to assess the effects of dose of the infectious agent on: (1) onset and prevalence of clinical signs, (2) severity of microscopic lesions, (3) presence and number of spores in cartilage of infected fish, and (4) the relative risk of infection for each fish species.

\section{METHODS}

Fish. The Mt. Lassen strain of rainbow trout and the Shasta strain of brown trout were obtained as eyed eggs from a private and state fish hatchery, respectively. The brown trout were an available hatchery strain and the rainbow trout were from a photo-period controlled facility that allowed matching of ages of the 2 fish species. The eggs were incubated in $13^{\circ} \mathrm{C}$ well water until hatching. The hatching of eggs for the rainbow trout and brown trout were completed within $3 \mathrm{~d}$ of each other. Fish were fed a commercial trout diet and held in $20 \mathrm{l}$ aquaria receiving $15^{\circ} \mathrm{C}$ well water prior to experimentation. Rainbow trout had an average age of $6 \mathrm{~d}$ and brown trout $8 \mathrm{~d}$ and both fish species had a mean weight of $0.2 \mathrm{~g}$ at the time experimentation began.

Collection and enumeration of triactinomyxon spores. Triactinomyxon spores were harvested from infected laboratory populations of aquatic oligochaetes that had been exposed previously to spores of $\mathrm{Myx}$ obolus cerebralis obtained from infected trout. Spores of $M$. cerebralis were collected by homogenizing the fresh heads of infected rainbow trout Oncorhynchus mykiss from the Mt. Whitney Fish Hatchery (Lone Pine, California) in a blender and passing the mixture through gauze to remove larger debris. The spores in solution were enumerated by the standard hemocytometer method and immediately added to Tubifex cultures in $20 \mathrm{l}$ aquaria $\left(15^{\circ} \mathrm{C}\right)$. These spores were the source for a continuous culture of the parasite passed sequentially through oligochaete (origin, Mt. Whitney hatchery) and rainbow trout hosts. Beginning 14 wk after exposure to spores, the triactinomyxon stages released from infected oligochaetes were trapped on $20 \mu \mathrm{m}$ mesh screens, resuspended in water, and an aliquot removed for enumeration. Replicate $0.1 \mathrm{ml}$ samples were placed on petri dishes with grids and the number of triactinomyxons counted. The total number of triactinomyxons in the sample was then estimated and dilutions were prepared to provide the desired concentrations for each exposure dose

Experimental exposures of trout. After enumeration, triactinomyxons from a single collection were dispensed into 2 replicate containers with $500 \mathrm{ml}$ of $15^{\circ} \mathrm{C}$ well water at each of 4 exposure doses $(10,100,1000$, 10000 triactinomyxons per fish). Thirty fish were added to each container. Two additional containers contained no triactinomyxons 10 triactinomyxons per fish). After $2 \mathrm{~h}$, the fish were removed from each con- 
tainer and placed into individual 201 aquaria receiving single pass $\left(0.51 \mathrm{~min}^{-1}\right) 15^{\circ} \mathrm{C}$ well water for the duration of the experiment. There were no attempts to determine the numbers of triactinomyxons that had discharged their sporoplasm cells but in our experience this is routinely ca $80 \%$. Fish were fed once or twice daily with a commercial trout ration.

Assessments of infection. Clinical signs and prevalence of infection: Fish were observed daily for the onset of clinical signs, including a tail chasing swimming behavior (whirling), and darkening of the caudal peduncle region (black tail). The week post exposure when clinical signs were first detected was recorded. At 5 mo post exposure, the 10 fish removed from each group for histological and spore concentration analyses were examined for the prevalence of black tail. Although gross signs of cranial and spinal deformities were noticed, we did not estimate their prevalence. The prevalence of infection among each treatment group was calculated from the total number of fish with spores (infected) over the total number of fish examined at 5 mo post exposure.

Histopathology scoring: Ten fish from each replicate group were collected at 5 mo post exposure for histopathological evaluation. Fish were anesthetized and cut transversely at the level of the dorsal fin. A new razor blade was used to make a midsaggital cut through the head. One side was stored at $-20^{\circ} \mathrm{C}$ for later spore concentration determinations (see next section). The other side of the head section was fixed in Davidson's solution for 48 to $72 \mathrm{~h}$, processed routinely into paraffin, sectioned at 4 to $6 \mu \mathrm{m}$, and stained with hematoxylin and eosin (Humason 1979). For photography and examination of the cranial and caudal part of the fish, additional fish of each species ( 2 control fish, and 2 high-dose exposure fish) at 5 mo post exposure were fixed whole in $10 \%$ neutral buffered formalin. The fish were decalcified in formic acid, transected midsagitally, and processed routinely for the preparation of hematoxylin and eosin (H\&E) stained tissue sections. Lesions associated with Myxobolus cerebralis infection (trophozoites, spores, and inflammation) were scored separately in 5 anatomical locations: gill, jaw, nares, cranium, and vertebrae/ribs/fin rays. Lesions were scored from 0 to 4 using the following guidelines:

(0) none-sections had no evidence of $M$. cerebralis;

(1) minimal-evidence of $M$. cerebralis was limited to a single focus, $<300 \mu \mathrm{m}$ in diameter;

(2) mild- $M$. cerebralis with associated inflammation was in a single focus up to $600 \mu \mathrm{m}$ in diameter, or up to 6 foci (each $<400 \mu \mathrm{m}$ in diameter);

(3) moderate $-M$. cerebralis with moderate associated inflammation; could be in a single focus $>600 \mu \mathrm{m}$ in diameter, or $>3$ foci with at least $1>400 \mu \mathrm{m}$ in diameter, or $>6$ foci with none $>400 \mu \mathrm{m}$ in diameter;
(4) severe- $M$. cerebralis with associated inflammation was severe in some areas; was always multifocal and in some areas invaded adjacent noncartilage tissue and/or distorted surrounding bone.

Also, a maximum lesion score was assigned to each fish based on the highest Myxobolus cerebralis lesion score in the 5 anatomical locations examined. For example, a fish with scores in the gill (score $=2$ ), jaw (score $=0$ ), nares (score $=0)$, cranium (score $=3$ ), and vertebrae/ribs/fin rays (score $=1$ ) would have a maximum lesion score $=3$. The relative abundance of eosinophilic granular leukocytes in cranial and spinal nerve roots was scored from 0 (none) to 5 (abundant). As a measure of energy stores, hepatocellular glycogen depletion was scored from 0 (none) to 3 (severe) directly from the size and appearance of vacuoles in the H\&E stained tissue sections. For quality control, the relative amount of tissue autolysis and sectioning artifact was scored from 0 to 5 . None of the sections had more than minimal autolysis (usually associated with bile leakage during fixation), and sections with more than moderate artifact were recut and reexamined.

Spore concentrations: Ten fish from each replicate of all exposure doses and the controls were examined for the presence and concentration of spores at 5 mo post exposure. As described previously, individual heads were used both for histological analyses and spore detection and enumeration. One half of the head was subjected to pepsin trypsin digestion as described by Markiw \& Wolf (1974a) with minor modifications. Fish were scored as infected if any spores were observed. The number of spores was then counted using both sides of a standard hemocytometer and reported as total spores per $1 / 2$ head. The minimum number of spores detected by this method was $1 \times 10^{3}$. The prevalence of infection (number of fish in which spores were detected divided by the total number of fish examined) was then determined at each dose of exposure. In addition, the mean spore concentrations were calculated for only those fish found to be infected at each dose. We did not include fish where spores were not detected for the mean spore concentration values since our objective was to examine spore burden as related to dose of exposure conditionally on a fish being infected.

Statistical analyses: A $10 \%$ level of significance was used whenever significance tests were performed for all evaluations of treatments. The prevalence of the infection was determined as the proportion of fish sampled containing spores at 5 mo post exposure. In order to evaluate differences in susceptibility between species at various doses, a ratio of the prevalence of infection in rainbow trout over the respective prevalence in brown trout for each dose of exposure was constructed. 
Since all fish in the sample were free from the infection at the beginning of the experiment and were all exposed to a selected dose, the prevalence of infection at each dose represented the risk of infection at 5 mo post exposure. The calculated prevalence ratios are referred to subsequently as risk ratios (RR). RR and the respective $90 \%$ confidence intervals $(\mathrm{CI})$ were calculated using the statistical software package STATA (Stata Statistical Software: Release 5.0, College Station, TX).

The comparisons of spore numbers were conditional on the fish having received an exposure to triactinomyxon stages; we therefore excluded the unexposed control group. A 2-way analysis of variance (ANOVA) (Kleinbaum et al. 1987, Neter et al. 1990) was used to assess the effect of species and dose on the number of spore present at 5 mo post exposure. Spores numbers were $\log _{10}$ transformed in an effort to make their distribution closer to normal. An interaction effect between species and dose was identified by the 2 -way ANOVA. Subsequently, main effects of species and dose were assessed separately using non-parametric tests (Mann \& Whitney 1947, Kraft \& Van Eeden 1968). Mann-Whitney tests were used to compare the median logarithms of number of spores in rainbow trout to brown trout for each dose level. Additionally, we used a non-parametric test for trend (Cuzick 1985, Stata 1997) in order to determine if a trend effect of infection dose on log number of spores existed for each fish species.

\section{RESULTS}

\section{Clinical signs and prevalence of infection}

No clinical signs of whirling disease were observed among control trout (non-exposed) of either species. Clinical signs were observed among rainbow trout at all doses of exposure to Myxobolus cerebralis. Among rainbow trout exposed to 10 triactinomyxons per fish signs (black tail) were observed in 1 fish at 5 mo post exposure. The prevalence of clinical signs among rainbow trout increased with dose and reached $100 \%$ at the highest dose of exposure (Table 1). Whirling behavior was detected among all rainbow trout groups that received doses greater or equal to 1000 triactinomyxons per fish. No abnormal swimming was observed among any of the brown trout regardless of dose of exposure. Black tails were not observed among brown trout that received doses of 10 or 100 triactinomyxons per fish. The greatest prevalence of black tail $(20 \%)$ was found among brown trout exposed to the highest dose (10000 triactinomyxons per fish). Black tails were first detected in the highest exposure groups at $6 \mathrm{wk}$ post exposure among rainbow trout compared to brown trout at $7 \mathrm{wk}$. The longest period to onset of black tail was among brown trout receiving 1000 triactinomyxons per fish at $11 \mathrm{wk}$ after exposure (Table 1). Skeletal deformities developed in all groups of rainbow trout exposed to doses greater or equal to 100 triactinomyxons per fish and in brown trout exposed to the 2 highest doses. No quantitative assessments of presence or prevalence were made due to the subjective nature of the criteria used to evaluate deformities.

The prevalence of infection (spores detected at $5 \mathrm{mo}$ post exposure) among groups of rainbow trout ranged from $30 \%$ at the lowest exposure dose to $100 \%$ at the highest exposure dose (Table 1). The prevalence of infection among groups of brown trout ranged from $5 \%$ at the lowest exposure dose to $85 \%$ at the 2 highest exposure doses. Evaluations of the differences in susceptibility (as determined by presence of spores) to Myxobolus cerebralis at each challenge dose were constructed using the ratio of the risk of infection in rainbow trout over the respective risk in brown trout 
Table 2. Myxobolus cerebralis infecting Oncorhynchus mykiss and Salmo trutta. Ratio of the risk of infection with $M$. cerebralis in rainbow trout over the respective risk in brown trout for each challenge dose. CI: confidence interval

\begin{tabular}{lcc|}
\hline Challenge dose & Risk ratio & $90 \% \mathrm{CI}$ \\
\hline 0 & $-^{\mathrm{a}}$ & $-^{\mathrm{a}}$ \\
10 & 1.31 & $1.1-32.8$ \\
100 & 1.21 & $0.96-1.78$ \\
1000 & 1.18 & $0.94-1.33$ \\
10000 & $1.01-1.37$ \\
\multicolumn{2}{l}{ a Values could not be determined since there were no } \\
infections among fish in control groups that were not \\
exposed to M. cerebralis
\end{tabular}

for each dose with their respective $90 \%$ CIs (Table 2). The $\chi^{2}$ test for heterogeneity of effect across strata (Stata 1997) was borderline significant $(p=0.1694)$ so we may infer that the above defined RR vary for each dose level. The dose specific RR show that rainbow trout were considerably more apt to be infected than brown trout at the challenge dose of 10 triactinomyxons per fish ( $\mathrm{RR}=6,90 \% \mathrm{CI}$ : 1.1 to 32.8 ) and slightly higher risk of infection at doses of 100,1000 and 10000 triactinomyxons per fish.

\section{Microscopic pathology}

Myxobolus cerebralis-associated lesion scores increased with the level of exposure in both species (Fig. 1). Based on the maximum lesion scores, rainbow trout showed approximately a 10 -fold greater susceptibility to microscopic pathological changes induced by the parasite. This is illustrated by the mean maximum lesion score for rainbow trout exposed to 100 triactinomyxons per fish exceeding the score for brown trout exposed to 1000 triactinomyxons per fish (Fig. 1). Also, the distribution of lesions was different in the 2 species. The most severe lesions in rainbow trout were usually in the cranium, and lesions in the cranium were dose-dependent. Lesions in brown trout were found more frequently in the vertebrae, fin rays, ribs, and gill arches than in the cranium (Fig. 1).

Compared with rainbow trout, brown trout had less inflammation associated with the various stages of Myxobolus cerebralis, particularly in the ribs. It was common to have central cartilage replaced by a small cluster of spores in several adjacent ribs (Fig. 2) in brown but not rainbow trout. Other morphologic features of $M$. cerebralis trophozoites, spores, cartilage degeneration, and associated inflammation in both species were similar to previous descriptions (Halliday 1974).

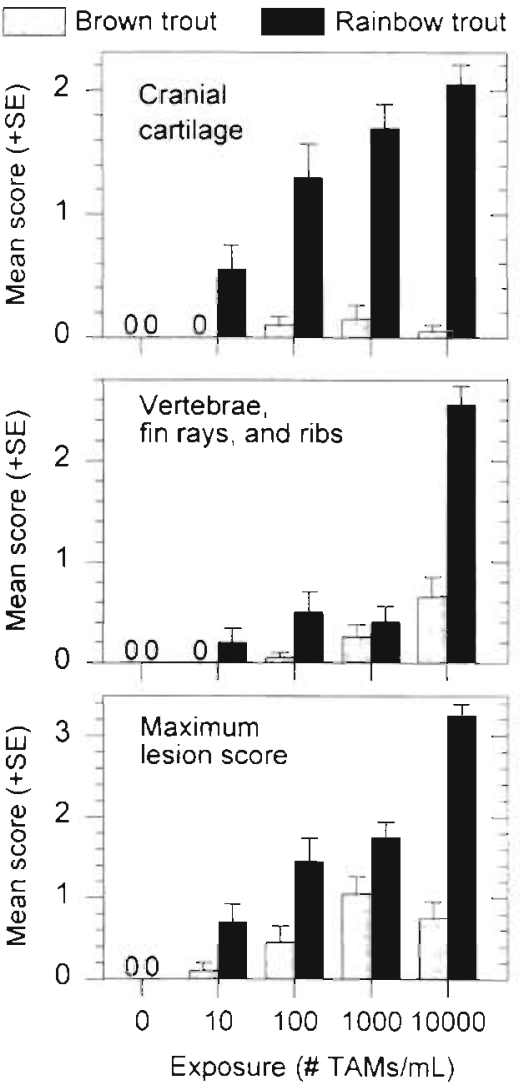

Fig. 1. Myxobolus cerebralis infecting Oncorhynchus mykiss and Salmo trutta. Severity of microscopic lesions among rainbow and brown trout 5 mo after exposure to graded doses of the infectious stages of $M$. cerebralis. Lesions were scored as none (0), minimal (1), mild (2), moderate (3), or severe (4). The maximum lesion score for each fish was the greatest value from the 5 anatomical regions that were scored. TAM: triactinomyxon

Eosinophilic granular leukocytes (EGLs) were common in cranial nerve ganglia and nerve roots of brown trout but not rainbow trout (Figs. $3 \& 4$ ). However, scores for EGLs were not associated with dose of exposure. Eosinophilic granules of EGLs stained much more intensely in the formalin-fixed decalcified sections than those preserved in Davidson's solution. Scored changes in hepatocellular glycogen, autolysis, and artifact had no clear patterns associated with fish species or dose of exposure.

\section{Spore concentrations in exposed fish}

Spores in the cranial regions were detected among rainbow trout in all exposed groups and among brown trout at all but the lowest dose of exposure (Table 3). The concentrations of spores ranged from none detected to $8.8 \times 10^{5}$ per $1 / 2$ head in rainbow trout (Table 3 ) and the mean $\log _{10}$ spore numbers tended to 


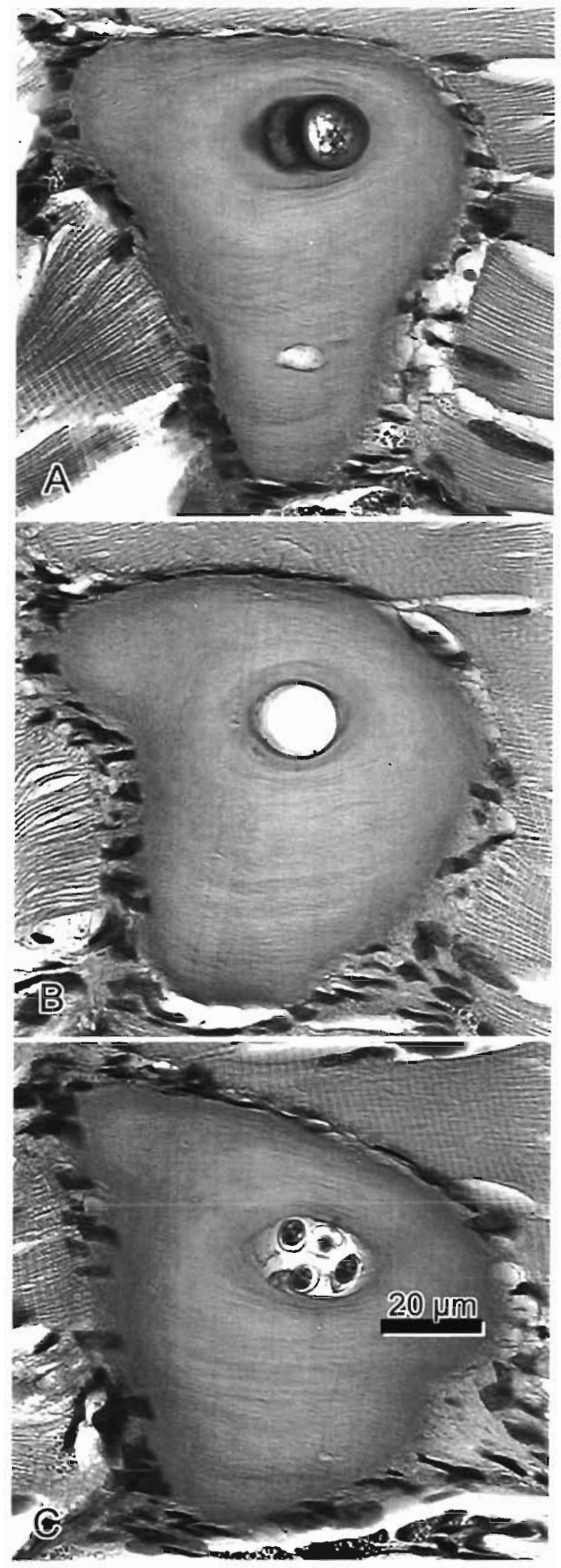

Fig. 2. Myxobolus cerebralis infecting Salmo trutta. Adjacent ribs in brown trout $5 \mathrm{mo}$ after exposure to $10000 \mathrm{M}$. cerebralis triactinomyxons per fish. Note the lack of inflammation. Magnification is the same in all parts of the figure. (A) Normal rib with central cartilage. (B) Rib with loss of central cartilage. (C) Rib in which $M$. cerebralis spores replace central cartilage

increase with dose of exposure in rainbow trout. A very significant interaction $(\mathrm{p}<0.001)$ between species of fish and dose of exposure was found by the ANOVA procedure, indicating that the effect of dose on mean spore numbers was different for each species. There was a significant positive trend of $\log _{10}$ spore number from the lowest to the highest doses for rainbow trout $(p=0.01)$ but not for brown trout $(p=0.58)$. MannWhitney non-parameteric tests indicated that for the lowest dose (10 triactinomyxons per fish) the median $\log _{10}$ spores were very similar between brown and rainbow trout $(p=0.62)$. In contrast, at the higher doses of 100,1000 and 10000 triactinomyxons per fish rainbow trout had substantially higher median $\log _{10}$ spores compared to brown trout ( $\mathrm{p}$-values: 0.006, 0.001 and $<0.0001$, respectively).

Spore numbers were similar among rainbow trout and brown trout with minimal microscopic lesions (Fig. 5). However, spore numbers increased in rainbow trout as microscopic lesion scores increased from minimal to moderate. This was in contrast to brown trout, where spore numbers remained constant as severity of microscopic lesion scores increased from minimal to moderate (Fig. 5).

\section{DISCUSSION}

Experimental exposures to graded doses of triactinomyxons provided the ability to assess the relative susceptibility of brown and rainbow trout to Myxobolus cerebralis infections. Brown trout were clearly more resistant than rainbow trout with respect to the onset of clinical signs, risk and severity of infections, and production of spores. These differential responses to the parasite in each fish species aid in explaining why certain wild brown trout populations escape the severe negative impacts observed in wild rainbow trout. However, experimental exposures to high doses of triactinomyxons (1000 and 10000 per fish) can overwhelm the innate resistance of brown trout, a finding that points to high exposure rates in locations where wild brown trout have suffered negative impacts due to whirling disease. Curiously, the disease that results from high exposure rates of brown trout differs from that seen in rainbow trout both in the absence of the radical swimming behavior and a lack of increasing parasite bur- 


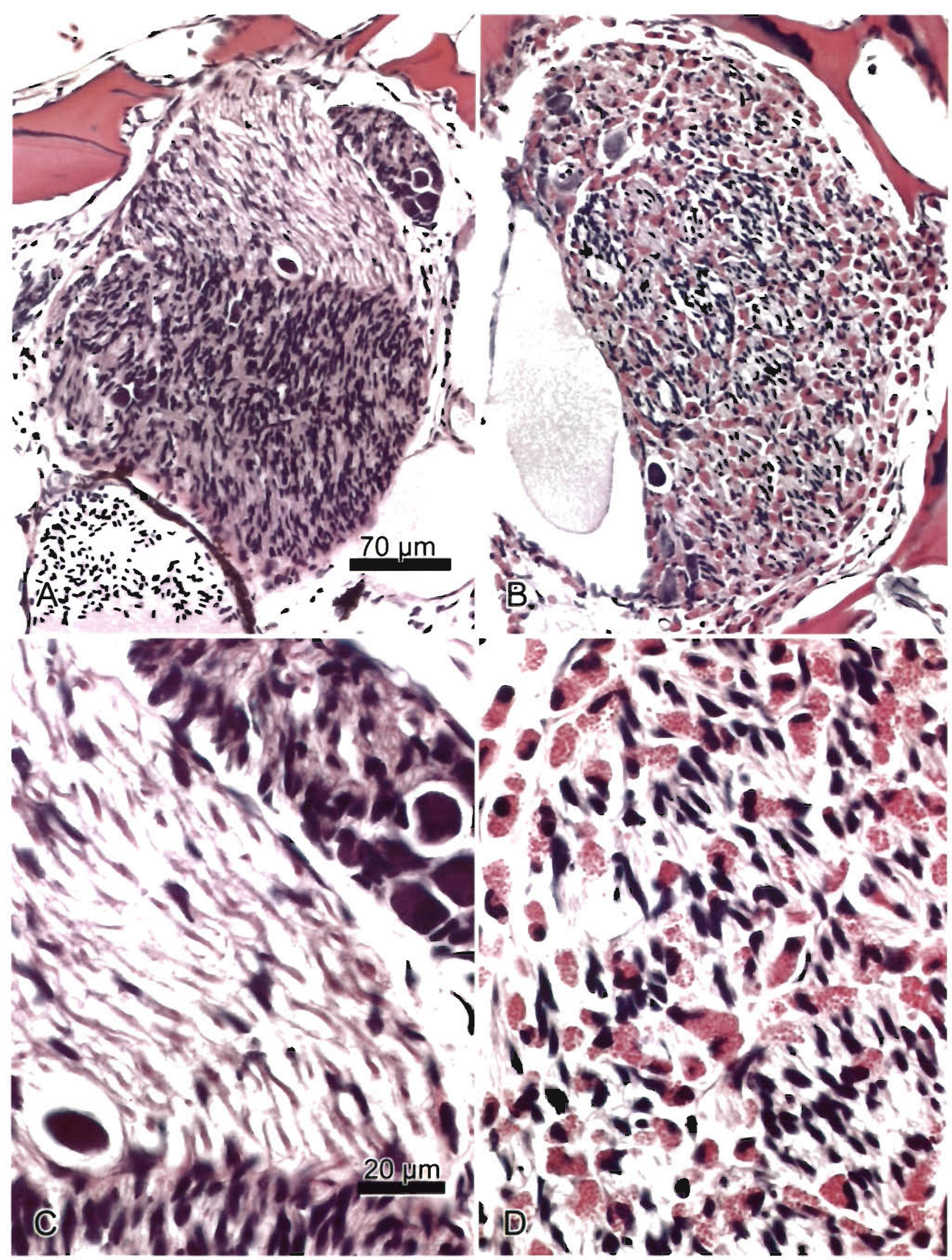

Fig. 3. Myxobolus cerebralis infecting Oncorhynchus mykiss and Salmo trutta. Cranıal nerve roots and gangha in decalcified sections from control fish. (A) Rainbow trout with no ganghonic eosinophilic granular leukocytes (EGLs). (B) Brown trout with abundant EGLs in a cranial ganglion and nerve root; same magnification as (A). (C) higher magnication of (A). (D) Higher 
Table 3. Myxobolus cerebralis infecting Oncorhynchus mykiss and Salmo trutta. Concentrations of spores in the cranial cartilage of rainbow and brown trout 5 mo after exposures to graded doses of the infectious stages of Myxobolus cerebralis. Replicate groups of 25 fish received either none (control) or graded doses of the infectious stages (triactinomyxons) of $M$. cerebralis. nd = none detected or below the limits of detection by the pepsin trypsin digestion method

\begin{tabular}{|llcccc}
\hline Species $^{d}$ & Dose $^{\mathrm{a}}$ & Replicate 1 & Replicate 2 & Mean $^{\mathrm{b}}$ & Range \\
\hline Rainbow & 0 & nd & nd & nd & nd \\
trout & 10 & $1.4 \times 10^{4}$ & $3.9 \times 10^{4}$ & $2.7 \times 10^{4}$ & nd $-4.1 \times 10^{4}$ \\
& 100 & $2.4 \times 10^{4}$ & $4.2 \times 10^{4}$ & $3.3 \times 10^{4}$ & nd - $1.5 \times 10^{5}$ \\
& 1000 & $4.2 \times 10^{4}$ & $3.6 \times 10^{4}$ & $3.9 \times 10^{4}$ & nd - $9.4 \times 10^{4}$ \\
& 10000 & $2.1 \times 10^{5}$ & $2.9 \times 10^{5}$ & $2.5 \times 10^{5}$ & $0.4-8.8 \times 10^{5}$ \\
Brown & 0 & nd & nd & nd & nd \\
trout & 10 & nd & $1.5 \times 10^{3}$ & $7.5 \times 10^{2}$ & nd - $1.5 \times 10^{3}$ \\
& 100 & $5.3 \times 10^{3}$ & $3.3 \times 10^{3}$ & $4.3 \times 10^{3}$ & nd - $1.1 \times 10^{4}$ \\
& 1000 & $8.8 \times 10^{3}$ & $2.0 \times 10^{4}$ & $1.4 \times 10^{4}$ & nd - 8.4 $\times 10^{4}$ \\
& 10000 & $3.9 \times 10^{3}$ & $3.0 \times 10^{3}$ & $3.5 \times 10^{3}$ & nd - $8.8 \times 10^{3}$
\end{tabular}

a Dose is expressed as the number of triactinomyxon stages of $M$ cerebralis per fish during a $2 \mathrm{~h}$ static exposure in $500 \mathrm{ml}$ of $15^{\circ} \mathrm{C}$ well water ${ }^{b}$ Spore concentrations are expressed as the mean per $1 / 2$ head of the number of positive fish among the 10 individual fish examined per replicate group. The remaining half of each head was processed for histological analyses

dens (spore concentrations) with greater doses of exposure. These differences in the pathogenesis of the disease presumably reflect host immunological responses to the parasite throughout its developmental cycle that are unique to each trout species.

The earliest reports of whirling disease among rainbow trout in Europe emphasized the relative resistance of brown trout (Hofer 1903). Halliday (1976) and O'Grodnick (1979) demonstrated that brown trout become infected but suffer few signs of the disease and produce significantly fewer spores than infected rainbow trout. These earlier investigations preceded our

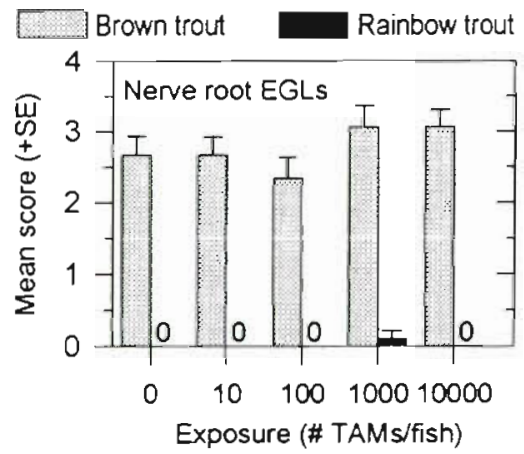

Fig. 4. Myxobolus cerebralis infecting Oncorhynchus mykiss and Salmo trutta. Mean scores for eosinophilic granular leukocytes (EGLs) in the cranial and spinal ganglia and nerve roots of rainbow trout and brown trout 5 mo after exposure to various concentrations of $M$. cerebralis triactinomyxons. Relative abundance of EGLs was scored as none (0), minimal (1), mild (2), moderate (3), moderately abundant (4), or extremely abundant (5). TAM: triactinomyxon current understanding of the life cycle of the parasite, including knowledge of the waterborne infectious stages (triactinomyxons); therefore, the doses received by the fish were unknown. These earlier investigators concluded that brown trout were resistant to whirling disease by co-evolution with the parasite on the Eurasian continent (Hoffman 1990). However, recent reports indicate that clinical whirling disease (black tail and skeletal deformities) occurs among wild and hatchery-reared brown trout in the intermountain west of the USA and Germany, respectively (R. Nehring, Colorado Division of Wildlife, Montrose, Colorado, unpubl. data; and $\mathrm{M}$. El-Matbouli pers. comm.).

It is unclear whether these recent occurrences of whirling disease in brown trout represent quantitative and/or qualitative changes to the parasite, the hosts, or differences in the environment (Hedrick 1998). Early assessments of the relative susceptibility of salmonids lacked information on: (1) the dose of triactinomyxons received, (2) matching of size and age of the fish, and (3) basic information on environmental factors such as water temperature (Hoffman \& Byrne 1974, Halliday 1976, El-Matbouli et al. 1992, Markiw 1992a). Despite these limitations, these early studies provided evidence that brown trout were indeed more resistant to whirling disease than several other salmonid species tested, including rainbow trout. Our laboratory trials demonstrated that brown trout are more resistant to infections with Myxobolus cerebralis than rainbow trout when dose, age, size of fish and water temperature were tightly controlled.

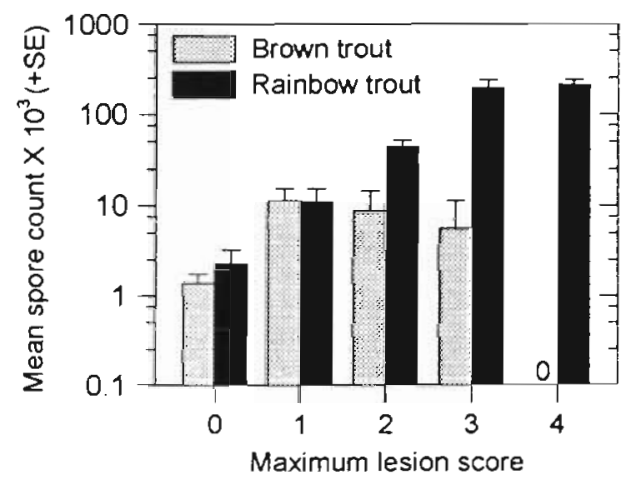

Fig. 5. Myxobolus cerebralis infecting Oncorhynchus mykiss and Salmo trutta. Comparison of mean $M$. cerebralis spore counts per $1 / 2$ head (determined using the digestion technique) in fish with various maximum lesion scores (determined using histopathology) 5 mo after exposure. Lesions were scored as none (0), minimal (1), mild (2), moderate (3), or severe (4). None of the brown trout had severe lesions 
In our trials, doses of 1000 triactinomyxons per fish or greater induced serious infections in brown trout but manifestations of the disease were clearly different than rainbow trout. This dose of infection appears high initially but modeling of triactinomyxon levels at 1 enzootic site (Colorado River) estimates wild trout may receive up to 20000 triactinomyxons fish $^{-1} \mathrm{~d}^{-1}$ (R. Nehring pers. comm.). At these doses of infection and those in our study, black tail and skeletal deformities were observed in brown trout, but the radical tail chasing swimming characteristic of whirling disease in rainbow trout was not detected. This finding is consistent with previous reports on naturally acquired infections in brown trout where the radical swimming 'or whirling' was not observed (Hoffman \& Putz 1969, Halliday 1976, O'Grodnick 1979).

The actual mechanisms by which Myxobolus cerebralis causes black tail and whirling are not understood. Schäperclaus (1986) suggested that impairment of sympathetic nerves controlling pigment motor functions result in black tail, while the whirling (whirling behavior or radical swimming) is due to utricular (inner ear) damage. More recently, compression of nerves in the anterior and caudal regions of the spinal cord by infections of surrounding vertebral cartilage were proposed as mechanisms that give rise to whirling and black tail, respectively ( $\mathrm{J}$. Rose, University of Wyoming, Laramie, Wyoming, pers, comm.). If this latter hypothesis is correct, the distribution and severity of lesions among infected brown trout must favor nerve damage in the caudal regions and the subsequent development of black tail. However, in rainbow trout where damage occurs throughout the axial skeleton, as found in our study and that of Markiw \& Wolf (1974b), both black tail and whirling behavior may occur. These differences in the distribution of $M$. cerebralis lesions between brown and rainbow trout were clearly evident in our study (Fig. 1). Baldwin et al. (1998) also found that gill arches of brown trout were more often involved than the ventral calvarium (cranium), which was the predominant site of microscopic lesions in rainbow trout. The presence of fewer parasites, distributed more in non-cranial cartilage and less inflammation in brown trout compared to rainbow trout, may in part explain why 'whirling' is not a common feature of the disease in brown trout.

Spore numbers found in infected fish have been used as an indicator of the severity of initial infection with Myxobolus cerebralis, a relationship first demonstrated by Markiw (1992b) in rainbow trout. She found spore concentrations reached $6.8 \times 10^{5}$ among fish held at $12.5^{\circ} \mathrm{C}$ for 6 mo after exposure of up to 10000 triactinomyxons per fish. Other studies with naturally acquired infections with $M$. cerebralis demonstrated spore concentrations over $2 \times 10^{6}$ per head for rainbow trout (Hoffman \& Byrne 1974, Markiw \& Wolf 1974b, O'Grodnick 1979). These levels of spores reported in rainbow trout from prior studies were very similar to those detected in our study (Table 3). In contrast to the rainbow trout in our study, brown trout demonstrated lower levels of spores, generally around $10^{4}$ per head. Curiously, our study also showed that spore concentrations in brown trout did not significantly increase with dose of exposure. The concentrations of spores found in brown trout from 'natural exposures' by O'Grodnick (1979) are similar to those we observed in experimentally exposed brown trout. The differences in spore concentrations and their relationships with exposure doses between rainbow and brown trout presumably reflect unique interactions between the host's immune response and the parasite.

The immune response to Myxobolus cerebralis has not been thoroughly investigated, although serum antibodies to spores have been reported (Griffin \& Davis 1978) and the strong cellular reaction in older cartilage lesions are recognized responses (Halliday 1974, Schäperclaus 1986). These host responses have the potential to retard or eliminate the parasites at each stage of development as they move through the 3 principal tissue compartments of skin, nerves, and cartilage in the fish (Hedrick et al. 1998). Clearly, greater numbers of parasites are reaching the spore stage in rainbow trout compared to brown trout (Table 3), an effect that becomes more pronounced between fish species with increasing doses of exposure. Increases in spore numbers with lesion severity suggests that granulomatous inflammation, often associated with the parasite, is less effective in destroying or restricting the parasite in rainbow trout than in brown trout. We presume, however, that additional quantitative and/ or qualitative differences in both the cellular and humoral immune responses contribute to differences in parasite numbers and gross and microscopic pathology of whirling disease in rainbow compared to brown trout.

EGLs in cranial nerve ganglia and nerve roots were first associated with naturally occurring infections with Myxobolus cerebralis among wild brown trout ( $\mathrm{E}$. MacConnell unpubl. obs.). Little is known about the function of EGLs in cranial and spinal nerve roots, but EGLs in rainbow trout have been associated with acute inflammation in the intestine and the immediate stress response in the gills (Powell et al. 1991, Holland \& Rowley 1998). In our study, scores for EGLs were not associated with exposure to triactinomyxons, but EGLs were clearly more prominent in brown trout compared to rainbow trout. It is interesting to speculate that these cells might play a role in limiting the number of parasites that enter or exit the nervous system during their migration to cartilage (El-Matbouli et al. 1996). 
Alternatively and independently of EGL functions, perhaps fewer parasites attach, invade and replicate in the early stages of infection in the epidermis of brown trout compared to rainbow trout. Initial studies by ElMatbouli et al. (1999) on early stages of infection with Myxobolus cerebralis suggest that attachment and invasion of the parasite occurs in a variety of both resistant and susceptible salmonid species and to a lesser extent even among some nonsalmonid fish. The subsequent survival of the parasite, however, differs greatly between salmonid and nonsalmonid fish (authors' unpubl. data), probably due to the functions of the cellular and humoral immune responses.

In summary, our studies show that under controlled conditions and at multiple doses of exposure, brown trout are clearly more resistant to infections with Myxobolus cerebralis than rainbow trout. The mechanisms by which fish resist infections with $M$. cerebralis are unknown but may involve both qualitative and/or quantitative differences in the humoral and cellular arms of the immune response. The EGLs, found more prominently in brown trout than rainbow trout, may represent a key cellular component acting in brown trout to limit $M$. cerebralis infection, an hypothesis currently being pursued. We are also investigating the immune response of coho salmon to $M$. cerebralis infections since this salmonid shows equal or greater resistance to the parasite than brown trout. The overall goal of these investigations is to understand the mechanisms underlying the unique means developed to combat the parasite in more resistant salmonid populations. The genes conferring resistance can then be exploited through breeding programs to improve the resistance of rainbow trout to $M$. cerebralis infections.

Acknowledgements. This work was supported in part by the US Fish and Wildlife Service and the California Department of Fish and Game and the Whirling Disease Foundation. We thank Jeff Drongensen, Pathologist, California Department of Fish and Game for his assistance in oligochaete and fish collections

\section{LITERATURE CITED}

Baldwin TJ, Peterson JE, McGhee GC, Staigmiller KD, Motteraum ES, Downs CC, Stanek DR (1998) Distribution of whirling disease, caused by Myxobolus cerebralis, in salmonid fishes in Montana. J Aquat Anim Health 10: $361-371$

Cuzick J (1985) A Wilcoxon-type test for trend. Stat Med 4: $87-90$

El-Matbouli M, Fischer-Scherl T, Hoffman RW (1992) Present knowledge of the life cycle, taxonomy, pathology, and therapy of some Myxosporea spp. important for freshwater fish. Annu Rev Fish Dis 3:367-402
El-Matbouli M, Hoffmann RW, Mandok C (1996) Light and electron microscopic observations on the route of the triactinomyxon-sporoplasm of Myxobolus cerebralis from epidermis into rainbow trout (Oncorhynchus mykiss) cartilage. J Fish Biol 46:919-935

El-Matbouli M, Hoffmann RW, Shoel H, McDowell TS, Hedrick RP (1999) Whirling disease: host specificity and interaction between the actinosporean stage of Myxobolus cerebralis and rainbow trout Oncorhynchus mykiss cartilage. Dis Aquat Org 35(1):1-12

Griffin BR, Davis, EM (1978) Myxosoma cerebralis: detection of circulating antibodies in infected rainbow trout (Salmo gairdneri). J Fish Res Board Can 35:1186-1190

Halliday MM (1974) Studies on Myxosoma cerebralis; a parasite of salmonids. II. The development and pathology of Myxosoma cerebralis in experimentally infected rainbow trout (Salmo gairdneri) fry reared at different water temperatures. Nord Veterinaermed 25:349-358

Halliday MM (1976) The biology of Myxosoma cerebralis; the causative agent of whirling disease of salmonids. J Fish Biol 9:339-357

Hedrick RP (1998) Relationships of the host, pathogen and environment: implications for diseases of cultured and wild fish populations. J Aquat Anim Health 10:107-111

Hedrick RP, El-Matbouli M, Adkison MA, MacConnell E (1998) Whirling disease: re-emergence among wild trout. Immunol Rev 166:365-376

Hofer B (1903) Über die Drehkrankheit der Regenbogenforelle. Allg Fisch-Ztg 28:7-8

Hoffman GL (1970) Intercontinental and transcontinental dissemination and transfaunation of fish parasites with emphasis on whirling disease (Myxosoma cerebralis). In: Snieszko SF (ed) Disease of fish and shellfish. American Fisheries Society, Washington, DC, p 69-81

Hoffman GL (1990) Myxobolus cerebralis, a worldwide cause of salmonid whirling disease. J Aquat Anim Health 2: $30-37$

Hoffmann GL, Byrne CJ (1974) Fish age as related to susceptibility to Myxosoma cerebralis, cause of whirling disease. Prog Fish Cult 36:151

Hoffman GL, Putz RE (1969) Host susceptibility and the effect of ageing, freezing, heat, and chemicals on the spores of Myxosoma cerebralis. Prog Fish Cult 31:35-37

Holland JW, Rowley AF (1998) Studies on the eosinophilic granule cells in the gills of the rainbow trout, Oncorhynchus mykiss. Comp Biochem Physiol 120:321-328

Humason G (1979) Animal tissue techniques. WH Freeman and $\mathrm{Co}$, San Francisco

Kleinbaum DG, Kupper LL، Muller KE (1987) Applied regression analysis and other multivariable methods, 2nd edn. Duxbury Press, Belmont, CA, p 718

Kraft CH, Van Eeden C (1968) A nonparametric introduction to statistics. The Macmillan Company, New York

Mann HB, Whitney DR (1947) On a test of whether one of two random variables is stochastically larger than the other Ann Math Stat 18:50-60

Markiw ME (1992a) Salmonid whirling disease. U.S. Department of Interior, Fish and Wildlife Service, Fish and Wildife Leaflet 17, Washington, DC, p 111

Markiw ME (1992b) Experimentally-induced whirling disease. I. Dose response of fry and adults of rainbow trout exposed to the triactinomyxon stage of Myxobolus cerebralis. J Aquat Anim Health 4:40-43

Markiw ME, Wolf K (1974a) Myxosoma cerebralis: isolation and concentration from fish skeletal elements - sequential enzymatic digestions and purification by differential centrifugation. J Fish Res Board Can 31:15-20 
Markiw ME, Wolf K (1974b) Myxosoma cerebralis: comparative sensitivity of spore detection methods. $J$ Fish Res Board Can 31:1597-1600

Nehring RB, Walker PG (1996) Whirling disease in the wild: the new reality in the intermountain west. Fisheries (Bethesda) 21:28-32

Neter J, Wasserman W, Kutner MH (1990) Applied linear statistical models, 3rd edn. IRWIN, Burr Ridge, IL

O'Grodnick JJ (1979) Susceptibility of various salmonids to whirling disease (Myxosoma cerebralis). Trans Am Fish Soc 108:187-190

Powell MD, Wright GM, Burka JF (1991) Degranulation of eosinophilic granule cells induced by capsaicin and substance $\mathrm{P}$ in the intestine of the rainbow trout (Oncorhynchus mykiss Walbaum). Cell Tissue Res 266:469-474

Editorial responsibility: Wolfgang Körting,

Hannover, Germany
Schäperclaus W (1931) Die Drehkrankheit in der Forellenzucht und ihre Bekämpfung. Z Fisherie 29:521-567

Schäperclaus W (1986) Fish diseases, Vol 2. AkademieVerlag, Berlin

Stata Reference Manual Release 5.0 (1997) Stata Reference Manual Release 5.0, Vol 2. Stata Press, College Station, TX, p 661

Vincent ER (1996) Whirling disease and wild trout: the Montana experience. Fisheries (Bethesda) 21:32-34

Wolf K. Markiw ME (1984) Biology contravenes taxonomy in the Myxozoa: new discoveries show alternation of invertebrate and vertebrate hosts. Science 225:1449-1452

Yoder WG (1972) The spread of Myxosoma cerebralis into native trout populations in Michigan. Prog Fish Cult 34 : 103-106

Submitted: February 9, 1999; Accepted: May 26, 1999 Proofs received from author(s): August 4, 1999 